\title{
A Citation Analysis of Atmospheric Science Publications by Faculty at Texas A\&M University
}

\section{Rusty Kimball, Jane Stephens, David Hubbard, and Carmelita Pickett}

\begin{abstract}
A citation analysis of publications produced by the Department of Atmospheric Sciences faculty at Texas A\&M University was conducted. This study included a detailed analysis of 5,082 cited publications by source, format, and age. TAMU Libraries holdings were then assessed using the works cited within the context of the $80 / 20$ rule. The sources cited were primarily journals ( 91 percent) and books (5 percent). Eighty percent of the cited journal articles were fulfilled by just 24 journal titles, thus adhering to the $80 / 20$ rule. The results were compared to those of previous citation studies in the sciences, with implications for collection management.
\end{abstract}

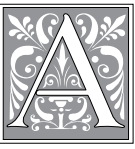

cademic libraries have a long history of analyzing collections for many purposes and are often trying to determine whether they are acquiring the appropriate scholarly content in support of academic departments. A citation analysis is a common research tool that allows libraries to conduct an assessment of their collection development efforts over time in support of specific disciplines. Understanding what format each discipline values as a core publication and how scholars disseminate their research findings are key considerations for libraries as they support traditional disciplines and interdisciplinary fields. Libraries have a complex task of monitoring and surveying the scholarly exchange to better understand what subscriptions to acquire and what open access initiatives to support. Libraries supporting scientific researchers must: maintain subscriptions to society publications and major Science, Technology, and Medicine (STM) publisher products; support discipline specific open access models; and, at some point, make significant investments in journal backfile collections. Taken together, these are costly investments compared to the costs associated with supporting disciplines in the humanities and social sciences.

Texas A\&M University is the flagship university for the Texas A\&M University System and is a land, sea, and space grant institution. The university opened in 1876 as the state's first public institu-

Rusty Kimball, Jane Stephens, and David Hubbard are Science and Engineering Librarians, and Carmelita Pickett is Head of Collection Development E Acquisitions Services, all at Texas AEM University Libraries; e-mail:rkimball@library.tamu.edu, jstephens@library.tamu.edu, hubbardd@library.tamu.edu,cpickett-k@ library.tamu.edu. (C) 2013 Rusty Kimball, Jane Stephens, David Hubbard, and Carmelita Pickett, AttributionNonCommercial (http://creativecommons.org/licenses/by-nc/3.0/) CC BY-NC 
tion of higher education with research strengths in the sciences. In support of the university's research strengths, TAMU Libraries maintain subscriptions to key society publications, large STM publisher content-and, over time, has made significant investments to secure access to journal backfile collections. In an attempt to understand the collection development practices of TAMU Libraries for specific science disciplines over the last several years, a group of Texas A\&M University librarians initiated a citation analysis to determine how well the library supports the research needs of the TAMU Atmospheric Sciences Department.

\section{Background}

Atmospheric Sciences concern the study of the atmosphere and include the subfields of Meteorology (with its focus on weather forecasting), and Climatology-the study of atmospheric changes (both natural and man-induced) over time (short-term and long-term)-expressed as "average" climates. The Atmospheric Sciences also include the study of planetary atmospheres.

The Department of Atmospheric Sciences is one of four departments of the College of Geosciences at Texas A\&M University, with its main campus located in College Station, Texas. The university presently has 38,000 undergraduates and 9,000 graduate students. The Department of Atmospheric Sciences currently has 20 faculty members and 17 research staff/ postdoctoral scientists. It spends more than $\$ 4,000,000$ per year for research expenses, has 75 research grants and contracts, and receives funding from the National Science Foundation, the National Aeronautics and Space Administration, the National Oceanic and Atmospheric Administration, the Department of Energy, and the Environmental Protection Agency. The Department's undergraduate program offers a B.S. in Meteorology and has 150 students. The graduate program offers a M.S. and Ph.D. in Atmospheric Science and has 55 graduate students.
The Department of Atmospheric Sciences has four main research areas: weather and forecasting, dynamical meteorology and climate dynamics, atmospheric chemistry, and physical meteorology. ${ }^{1}$

\section{Literature Review}

The body of research making up collection analyses comes in different forms, implements various methodologies, and analyzes different variables (depending on study goals). Some analyses are local to a single university; some focus on multiple universities; some focus on a single subject; others are cross-disciplinary. User groups studied (such as faculty or students) and years covered also vary. These differences make comparisons more difficult, although general trends are discernible.

The type of material found in the reference list at the end of article, book, chapter, or other work can often be an indication of the type of publication a researcher cites most often in his overall research. Analyses of these references in the sciences and social sciences have found that researchers primarily cite journal articles, followed by books, ${ }^{2}$ while the researchers in the arts and humanities cite books most frequently. ${ }^{3}$ Despite this general trend, format citation patterns vary among science researchers. Investigators have reported that biology researchers cited journals from approximately 75 percent to 94 percent. ${ }^{4}$ Chemistry researchers cited journals at 79 percent $t^{5}$ and 85.8 percent. ${ }^{6}$ Researchers in geoscience and its subfields have cited articles from 64 percent to 83 percent. $^{7}$ After articles, science researchers rely next on books, but these rates also vary. ${ }^{8}$

Interestingly, those investigators who analyzed citations across disciplines reported lower percentages of journal use for the sciences as a whole than did the investigators who analyzed citations from specific science subjects, such as biology and chemistry. Leiding analyzed local undergraduate honors theses and reported that students in the sciences 
cited more journals than did students in the other disciplines; they cited journals at 58.8 percent. ${ }^{9}$ Smith analyzed local dissertations and reported that science students cited journals at 79 percent in 1991 and at 64 percent in 2001. ${ }^{10}$

Some investigators attempted to determine differences in citation patterns among user groups. These studies provide evidence, albeit conflicting, that there are differences between faculty and student citation patterns. ${ }^{11}$

The actual scattering of journal titles (number and distribution of titles accounting for 100 percent of the citations) varied among studies. However, articles cited by science researchers tended to follow the $80 / 20$ rule $^{12}$ ( 80 percent of the article citations are fulfilled by 20 percent of the journal titles). Investigators, who did not discuss results in terms of this rule, also provided evidence that a large number of frequently cited articles were fulfilled by a small number of titles. ${ }^{13}$

Cross-disciplinary studies reported that science researchers cite some of the oldest material ${ }^{14}$ - yet the most frequently cited material is more current. ${ }^{15}$ Vallmitjana and Sabate found that the mean age of citations in their chemistry dissertations was 14 years and the median age was 9 years; 90 percent were 31 years or younger; and the range was 145 years. ${ }^{16}$ Gooden's reported age range for chemistry dissertations was 182 years. ${ }^{17}$ For biology graduate students, Miller reported an average article age 10.6 years with a median of 8 years; the most frequently occurring age was four years; and the range was 175 years. ${ }^{18}$ Breaking down fields into subfields revealed additional patterns. ${ }^{19}$ Within geosciences, Walcott reported that geophysics citations spanned the longest period (292 years) and geochemistry spanned the shortest time (97 years).$^{20}$

Some investigators attempted to determine the impact that the Internet has had on citation patterns. Conkling, Harwell, McCallips, Nyana, and Osif reported that format changes for sciences (astronomy, biochemistry, geology and physics) var- ied in significance by science subfield and/or by university. Journals remained the predominant format cited, but their number increased while book citations decreased postweb. ${ }^{21}$ Smith also performed a pre- (1991) and postweb (2001) local analysis of theses and dissertations across disciplines. ${ }^{22}$ She too found that journal citations in the sciences remained dominant, although they decreased in use while book citations increased.

The Internet may also have an impact on the age of material cited by researchers. For the sciences, Conkling et al. reported statistically significant changes depending on subfield and/or university..$^{23}$ These authors speculated that the citations to older material might be due to online journal backfiles being purchased by university libraries, making the journals easily accessible. For science, Smith reported that citations to current year publications increased to 80 percent postweb and that postweb citations extended back further in time. ${ }^{24}$

\section{Purpose of Study \\ Objectives}

To date, there have been no known citation analyses conducted on publications by atmospheric scientists - this study fills that gap. The main objectives to be answered by this study are to determine the following issues: 1) how well the TAMU Libraries collection meets the needs of faculty researchers in the TAMU Atmospheric Sciences Department by asking what sources were cited by these authors, and does TAMU Libraries own them in electronic or print format; 2) what types of publications are cited by the authors; and 3) the ages of the cited publications. The findings of this study should identify material that needs to be added to the collection, as well as provide assistance with the selection of material for placement in remote storage.

\section{Methodology Faculty Publications}

Publications of the TAMU Department 
of Atmospheric Sciences were acquired from Thomson Reuters' Web of Science. Publications were found by searching the department name and ZIP code in the Address field of "Web of Science" (that is, Atomsph* SAME 77843) and limiting the publication years to 2008 and 2009 . The answer set was refined further to include only journal articles, proceedings, and review articles. The results were then exported to EndNote and an Excel spreadsheet. Local holdings were checked to determine whether TAMU Libraries has online or print access to the cited journals. To clarify cited works in subsequent analyses, a PDF of each faculty publication was attached to their respective record in the EndNote library for consultation.

\section{Cited Works}

The cited works of each faculty publication were located in "Web of Science" and exported into a spreadsheet. An alphanumeric code was assigned to each publication so that cited works could be tracked back to the original faculty publication. The spreadsheet was then divided into journals and nonjournals spreadsheets. An International Standard
Serial Number (ISSN) was added to the journals spreadsheet, which provided the basis for tabulating and sorting. A table of the most frequently cited journals was then compiled, which was composed of journals responsible for 80 percent of all cited journal articles. The age of the journal articles (the difference between the date of original article and the date of the publication cited) was also calculated and added to the spreadsheet.

After examining the nonjournal literature cited, a classification scheme was developed and the cited works sorted into their respective categories. Individual titles of the nonjournal literature were then checked to see if the cited work was locally accessible or owned. The number and percentage of all publication categories owned by TAMU Libraries was then determined. The age of the nonjournal publications was also calculated and added to the spreadsheet.

\section{Results}

Faculty in the Atmospheric Sciences cited journal articles most frequently (see table 1). Of the 5,082 total citations, 4,610 (91\%) were to journal articles. This faculty also cited monographs (albeit to a lesser extent

\begin{tabular}{|l|c|c|}
\hline \multicolumn{3}{|c|}{ TABLE 1 } \\
\hline Citations by Format \\
\hline Journals (Articles) & $\begin{array}{c}\text { Number of } \\
\text { Citations }\end{array}$ & $\begin{array}{c}\text { \% of Total } \\
\text { Citations }\end{array}$ \\
\hline Books and Book Chapters & 4,610 & 91 \\
\hline Reports, including Planning, Policy, \& Technical & 258 & 5 \\
\hline Conference Papers and Proceedings & 92 & 1.8 \\
\hline Theses \& Dissertations (T\&D) & 58 & 1 \\
\hline Computer Programs & 20 & 0.4 \\
\hline Government Documents & 12 & 0.2 \\
\hline Other & 11 & 0.2 \\
\hline Manuals/Documentation (Mostly for Software) & 9 & 0.2 \\
\hline Maps & 7 & 0.1 \\
\hline Data Sets & 3 & 0.06 \\
\hline Total & 2 & 0.04 \\
\hline
\end{tabular}




\begin{tabular}{|c|c|c|c|c|}
\hline \multicolumn{5}{|c|}{$\begin{array}{c}\text { TABLE } 2 \\
\text { Most Frequently Cited Journals Ranked by Frequency }\end{array}$} \\
\hline Rank & Journal Name & $\begin{array}{c}\text { Number } \\
\text { of Articles }\end{array}$ & $\begin{array}{c}\% \text { of } \\
\text { Total } \\
\text { Journal } \\
\text { Citations }\end{array}$ & $\begin{array}{c}\text { Cumulative } \\
\text { \% of Total } \\
\text { Journal } \\
\text { Citations }\end{array}$ \\
\hline 1 & Journal of Geophysical Research: Atmospheres & 789 & 17 & 17 \\
\hline 2 & Journal of the Atmospheric Sciences & 446 & 10 & 27 \\
\hline 3 & Geophysical Research Letters & 265 & 6 & 33 \\
\hline 4 & Journal of Climate & 184 & 4 & 37 \\
\hline 5 & Applied Optics & 182 & 4 & 40 \\
\hline 6 & Atmospheric Environment & 164 & 4 & 44 \\
\hline 7 & Science & 147 & 3 & 47 \\
\hline 8 & Monthly Weather Review & 146 & 3 & 50 \\
\hline 9 & Atmospheric Chemistry and Physics & 138 & 3 & 53 \\
\hline 10 & Journal of Applied Meteorology & 117 & 3 & 56 \\
\hline 11 & $\begin{array}{l}\text { IEEE Transactions on Geoscience and } \\
\text { Remote Sensing }\end{array}$ & 100 & 2 & 58 \\
\hline 12 & $\begin{array}{l}\text { Quarterly Journal of the Royal } \\
\text { Meteorological Society }\end{array}$ & 97 & 2 & 60 \\
\hline 13 & Journal of Geophysical Research: Planets & 96 & 2 & 62 \\
\hline 14 & $\begin{array}{l}\text { Journal of Quantitative Spectroscopy \& } \\
\text { Radiative Transfer }\end{array}$ & 95 & 2 & 64 \\
\hline 15 & The Journal of Physical Chemistry. A & 78 & 2 & 66 \\
\hline 16 & Bulletin of the American Meteorological Society & 74 & 2 & 68 \\
\hline 17 & Aerosol Science and Technology & 71 & 2 & 69 \\
\hline $18=$ & Nature & 68 & 1 & 71 \\
\hline 18 & Journal of Atmospheric and Oceanic Technology & 68 & 1 & 72 \\
\hline 19 & Environmental Science \& Technology & 64 & 1 & 74 \\
\hline $20=$ & Journal of Chemical Physics & 41 & 1 & 74 \\
\hline 20 & Atmospheric Research & 41 & 1 & 75 \\
\hline 21 & Journal of the American Chemical Society & 39 & 1 & 76 \\
\hline $22=$ & Chemical Physics Letters & 37 & 1 & 77 \\
\hline 22 & $\begin{array}{l}\text { Proceedings of the National Academy of } \\
\text { Sciences of the United States of America }\end{array}$ & 37 & 1 & 78 \\
\hline 23 & Journal of Aerosol Science & 35 & 1 & 79 \\
\hline 23 & Air \& Waste Management Association & 30 & 1 & 79 \\
\hline 24 & $\begin{array}{l}\text { Journal of the Optical Society of America. A, } \\
\text { Optics, Image Science, and Vision }\end{array}$ & 28 & 1 & 80 \\
\hline 25 & Optics Express & 26 & 1 & 80 \\
\hline $26=$ & Icarus & 24 & 1 & 81 \\
\hline 26 & Journal of Physical Chemistry & 24 & 1 & 81 \\
\hline
\end{tabular}




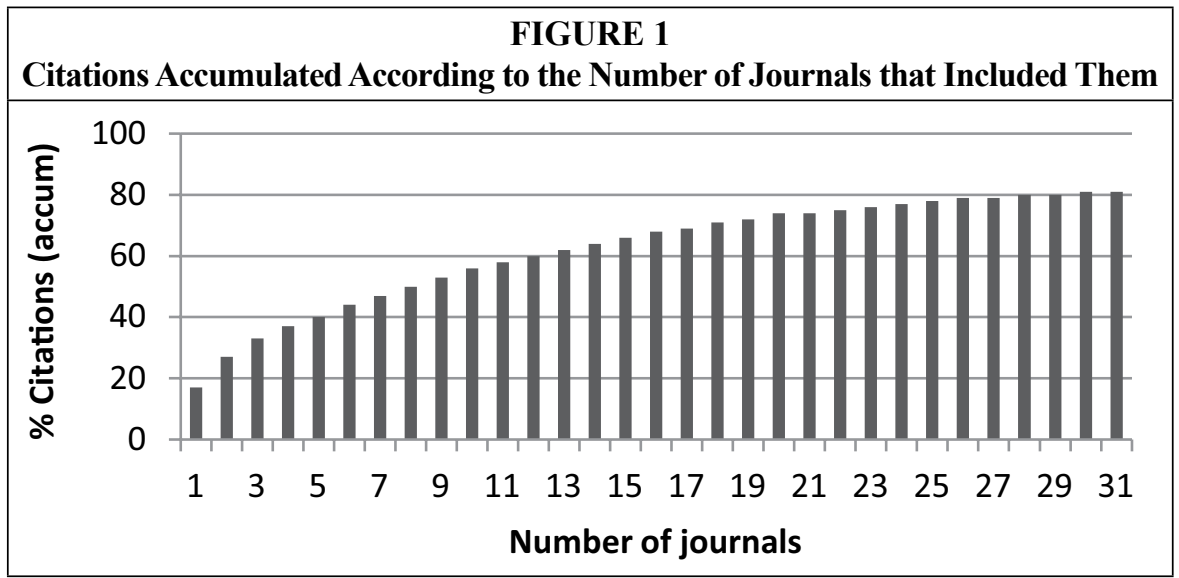

at $5 \%$ ), followed by reports $(1.8 \%)$, and conference papers and proceedings $(1 \%)$. The remaining format categories were cited at below 1 percent with the lowest (data sets) at 0.04 percent.

\section{Journals}

The original 119 Atmospheric Science faculty publications consisted of 113 journal articles and six review articles. These 119 publications contained citations to 4,610 journal articles from 297 different journals. The 31 most frequently cited journals from this set are shown in table 2. As shown in this table, the top three journals, which included 33 percent of all cited articles, were the Journal of Geophysical Research (JGR)-Atmospheres (17\%); the Journal of Atmospheric Sciences (10\%), and Geophysical Research Letters (6\%). Four "ties" occurred in the totals with journals with equal numbers of articles for the 18th, 20th, 22nd, and 26th places. The cumulative percent of the total of the journal citations hits 80 percent with the journal at 24th place, thus following the $80 / 20$ Rule with 80 percent of the most cited journal titles being fulfilled within just the top 8 percent of the titles.

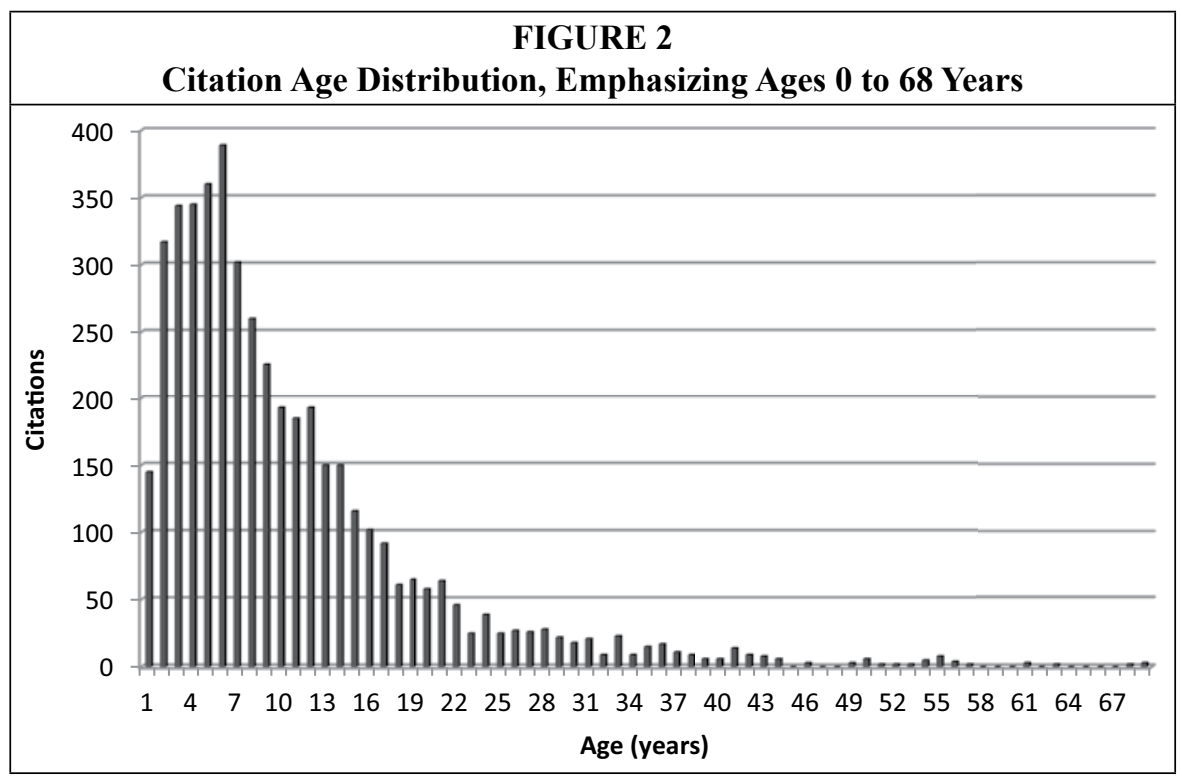


The 31st journal listed ranks 26th in the listing due to the four "ties." This cumulative percentage data is presented graphically in figure 1. Here, the cumulative percent of the total of the journal citations is presented as a bar graph. This figure illustrates how well the data follows the $80 / 20$ rule.

Figure 2 illustrates the distribution of the journal citations by age. Notably, the highest number of citations (389) occurs at the age of five years, with the oldest shown citation age of 67 years. Not shown in the figure are several outliers: two at 100 years, and one each at 104 years, 108 years, 128 years, 156 years, and the very oldest at 323 years. Among the oldest cited titles were an article from the Proceedings of the Royal Society of London from 1880, an article from the Transactions of the Cambridge Philosophical Society from 1852, and another from the Philosophical Transactions of the Royal Society of London from 1686. As shown in table 3, TAMU Libraries owned 99.3 percent of the 4,610 journal articles cited by TAMU Atmospheric Science faculty.

\begin{tabular}{|l|c|}
\hline \multicolumn{2}{|c|}{$\begin{array}{c}\text { TABLE 3 } \\
\text { Libraries }\end{array}$} \\
\hline Format & $\begin{array}{c}\text { \% Held by } \\
\text { Texas A\&M } \\
\text { Libraries }\end{array}$ \\
\hline Journals (Articles) & 99.3 \\
\hline Books and Book Chapters & 86.5 \\
\hline Conference Papers and Proceedings & 47 \\
\hline Maps & 33 \\
\hline Computer Programs & 0 \\
\hline Data Sets & 0 \\
\hline Government Documents & 82 \\
\hline $\begin{array}{l}\text { Manuals/Documentation (Mostly } \\
\text { for Software) }\end{array}$ & 0 \\
\hline $\begin{array}{l}\text { Reports, including Planning, Policy, } \\
\text { \& Technical }\end{array}$ & 2 \\
\hline Theses \& Dissertations (T\&D) & 30 \\
\hline Other & 1 \\
\hline
\end{tabular}

\section{Nonjournal Age}

Of the 472 nonjournal items cited, more than half were less than ten years in age (see table 4). The oldest nonjournal citation was to a 73-year-old conference paper. Those citations that were less

\begin{tabular}{|l|c|c|c|}
\hline \multicolumn{4}{|c|}{ TABLE 4 } \\
\multicolumn{1}{|c|}{ Cormat } & $\begin{array}{c}\text { Average } \\
\text { Age }\end{array}$ & $\begin{array}{c}\text { Oldest } \\
\text { Cited }\end{array}$ & $\begin{array}{c}\text { Newest } \\
\text { Cited }\end{array}$ \\
\hline Journals & 10.1 & 323 & $<1$ \\
\hline Books and Book Chapters (Book) & 15.6 & 58 & $<1$ \\
\hline Conference Papers and Proceedings (Conf) & 7.6 & 73 & $<1$ \\
\hline Maps & 14.3 & 34 & 4 \\
\hline Computer Programs & 8.4 & 16 & 2 \\
\hline Data Sets* & N/A & N/A & N/A \\
\hline Government Documents & 15.9 & 43 & 2 \\
\hline Manuals/Documentation (Mostly for Software) & 6.4 & 12 & 3 \\
\hline Reports, including Planning, Policy, \& Technical & 10.5 & 62 & 1 \\
\hline Theses \& Dissertations (T\&D) & 9.1 & 59 & 1 \\
\hline Other & 1.6 & 6 & $<1$ \\
\hline *Age not given. & & & \\
\hline
\end{tabular}


than a year old were to books, conference items, and "other" items. Government documents and books averaged 15.9 and 15.6 years, respectively. The longest age range observed was in conference items (from less than one year to 73 years), followed by reports (from one to 62 years). The age ranges for books and theses and dissertations were very close (from less than one year to 58 and from one year to 59 , respectively). The shortest age range in years was seen in the two categories of manuals and "other" (from three to twelve and from less than one year to six years, respectively).

\section{Nonjournal Holdings}

Of the 472 nonjournals cited by the atmospheric faculty, 276 (58.5\%) titles are owned by the TAMU Libraries, and 135 $(25.8 \%)$ are freely available on the web, leaving only $61(12.9 \%)$ not owned or immediately accessible. None of the 258 books cited are freely available on the web. Almost half of the total 58 conference papers cited are freely available, and more than two-thirds of the 92 reports cited are freely available on the web. Considering the books cited that were not owned by the library, eleven titles had pre-1979 publication dates, fourteen were published in the 1990s, and eleven were published in the 2000s. They were published by standard academic publishers (such as Wiley, Academic Press, various university presses). With a few exceptions, nothing unusual could be attributed to these books not owned by the library. A small number of these books were published by publishers not routinely covered by the library's Approval Plan. One title was a foreign language book published in Germany, two were published by China Meteorological Press, and two were published by small presses in the United States.

\section{Discussion}

\section{Format Dispersion}

This study confirms the importance of journals to science researchers. However, previous citation analyses have reported article citation rates that are lower and book rates that are considerably higher than rates reported in the current study (see table 5).

Investigators have reported conflicting results for book citation rates over time. Leiding reported book use to be higher preweb, but could not determine a trend..$^{25}$ For sciences, Conkling et al. reported a decrease in book citations ${ }^{26}$ while Smith reported an increase. ${ }^{27}$ Regardless, faculty in the current study cited books at a rate notably lower than those reported in the studies summarized in table 5 .

\section{Journal Title Dispersion (the 80/20 Rule) and Holdings}

Journal title dispersion in the current study supports the findings of previous science analyse ${ }^{28}$ by following the $80 / 20$ Rule, which states: " 80 percent of use is derived from 20 percent of the titles." ${ }^{29}$ In fact, 80 percent of the cited references in the current study were contained in only 24, or 8 percent, of the 297 journals cited. The TAMU Libraries owns at least 90 percent of all material cited by the atmospheric science faculty (99.3 percent of journals and 86.5 percent of books - see table 3). However, as Leiding pointed out, focusing on the holdings of all titles cited is misleading. ${ }^{30}$ Considering holdings in the context of the 80/20 Rule, a better focus would be on the ownership of the most cited titles. While other studies reported a high percentage of ownership for frequently cited titles, ${ }^{31}$ the TAMU Libraries is fortunate in being able to provide 100 percent of the most frequency cited titles (top 20 percent). Confirmation that libraries own the majority of the most cited journal titles in a given area would be an indication that the collection development practices for that portion of the collection are effective.

Some investigators have speculated that ownership and/or ease of access has contributed to these materials being cited more frequently. In her 1994 article, Walcott emphasized the importance of 


\begin{tabular}{|c|c|c|c|c|c|}
\hline \multicolumn{6}{|c|}{$\begin{array}{c}\text { TABLE } 5 \\
\text { Citations by Format within Science Disciplines in Previous Studies }\end{array}$} \\
\hline \multicolumn{6}{|c|}{ Biology \& Marine Science } \\
\hline Author & Users & Year Range & $\begin{array}{l}\text { \% Journal } \\
\text { Articles }\end{array}$ & \% Books & $\begin{array}{l}\% \text { Conference } \\
\text { Proceedings }\end{array}$ \\
\hline McCain & $\begin{array}{c}\text { F \& } \\
\text { Gs }\end{array}$ & $1975-1977$ & $\begin{array}{c}\text { F\& GS } 91 \\
\text { F } 88 \\
\text { PhD } 94 \\
\text { GS } 91\end{array}$ & $\mathrm{~N} / \mathrm{A}$ & $\mathrm{N} / \mathrm{A}$ \\
\hline Crotteau & $\mathrm{F}$ & $1989-1990$ & 84 & & \\
\hline Pancheshnikov & $\begin{array}{l}\text { F \& } \\
\text { GS }\end{array}$ & $2002-2004$ & $\begin{array}{c}\text { F\&GS } \sim 75 \\
\text { F } \sim 89 \\
\text { GS } \sim 78\end{array}$ & $\begin{array}{c}\mathrm{F} \& \mathrm{GS} \sim 10 \\
\mathrm{~F} \sim 9 \\
\mathrm{GS} \sim 13\end{array}$ & \\
\hline Miller & GS & 2006-2009 & 84 & 11 & \\
\hline Walcott 1994 Marine Science & $\mathrm{F}$ & $1986-1991$ & 78.8 & 21.2 & \\
\hline \multicolumn{6}{|c|}{ Chemistry, Physics \& Astronomy } \\
\hline Gooden & GS & $1996-2000$ & 85.8 & 8.4 & \\
\hline $\begin{array}{l}\text { Vallmitjana (incl Chemical } \\
\text { Eng) }\end{array}$ & GS & 1996-2003 & 79 & 12 & N/A \\
\hline Conkling Astronomy & GS & $\begin{array}{l}1990-1993 \\
2003-2006\end{array}$ & $\begin{array}{l}82 \\
88\end{array}$ & $\begin{array}{c}10 \\
6\end{array}$ & $\begin{array}{l}6 \\
3\end{array}$ \\
\hline $\begin{array}{l}\text { Conkling } \\
\text { Biochemistry }\end{array}$ & GS & $\begin{array}{l}1990-1993 \\
2003-2006\end{array}$ & $\begin{array}{l}91 \\
94\end{array}$ & $\begin{array}{c}7 \\
5.7\end{array}$ & $\begin{array}{l}0.8 \\
0.4\end{array}$ \\
\hline Conkling Physics & GS & $\begin{array}{l}1990-1993 \\
2003-2006\end{array}$ & $\begin{array}{l}82 \\
76\end{array}$ & $\begin{array}{c}8 \\
11\end{array}$ & $\begin{array}{l}4 \\
3\end{array}$ \\
\hline \multicolumn{6}{|c|}{ Geosciences } \\
\hline Walcott 1991 Geoscience & GS & $1981-1985$ & 80 & & \\
\hline Walcott 1991 Paleontology & GS & & 73 & 24 & \\
\hline Walcott 1991 Geology & GS & & 80 & 15 & \\
\hline Walcott 1991 Geophysics & GS & & 83 & 12 & \\
\hline Walcott 1991 Geochemistry & GS & & 80 & 16 & \\
\hline Conkling Geology & GS & $\begin{array}{r}1990-1993 \\
2003-2006\end{array}$ & $\begin{array}{l}64 \\
75\end{array}$ & $\begin{array}{l}24 \\
19\end{array}$ & $\begin{array}{l}6 \\
3\end{array}$ \\
\hline $\begin{array}{l}\text { Kimball Atmospheric } \\
\text { Sciences }\end{array}$ & $\mathrm{F}$ & 2008-2009 & 91 & 5 & 1 \\
\hline \multicolumn{6}{|c|}{ Sciences (Cross-disciplinary Studies That Included Results in Sciences) } \\
\hline Smith & & & & & \\
\hline & GS & $\begin{array}{c}1991 \& \\
2001\end{array}$ & $\begin{array}{l}79 \\
64\end{array}$ & $\begin{array}{l}14 \\
18\end{array}$ & \\
\hline Leiding & $\begin{array}{l}\text { Honor } \\
\text { UG }\end{array}$ & $1993-2003$ & 58.6 & 20.2 & \\
\hline Conkling & GS & $\begin{array}{l}1990 \mathrm{~s} \& \\
2000 \mathrm{~s}\end{array}$ & $\begin{array}{l}76 \\
82\end{array}$ & $\begin{array}{c}14 \\
9\end{array}$ & $\begin{array}{l}3 \\
3\end{array}$ \\
\hline
\end{tabular}


providing easy physical access to the types of materials important to her faculty. ${ }^{32}$ Conkling et al. speculated that the increased use of journal articles pre- to postweb for all but two subjects "might be a reflection of the ease with which researchers can access these materials on the Web." ${ }^{33}$ For astronomy, they reported an increased use of older material in the postweb era and suggested the possibility that universities might have acquired access to online backfiles of journals, which may have led to increased use and subsequent citation of these journals. On the other hand, Smith reported that the type of material cited by her local researchers from pre- to postweb did not always reflect availability (ownership). ${ }^{34}$ Citation analyses cannot determine if users cite titles because of their availability and/ or ease of access,,$^{35}$ but it is interesting to note that holdings evaluated in the current analysis, as in other analyses, tend to include the most cited titles.

\section{Publication Age}

The results of this study support the findings of previous science analyses with regard to the age of material cited. In general, science researchers do occasionally cite older materials, but newer publications are cited most frequently. ${ }^{36}$ In 1981, McCain and Bobick reported that the most frequently cited journals conform to Griffith's half-life model, which asserts that 50 percent of the "citedness" of a volume is completed within five years, and 90 percent within twenty years. ${ }^{37}$ This pattern seems to hold true for the sciences ${ }^{38}$ and is supported by the findings of the present study (see figure 2). Such citation age findings have implications for collection management (particularly preservation, weeding and storage, and journal backfile decisions) - as well as for interlibrary loan.

\section{Conclusions}

From the analysis, the authors conclude that, in their 119 publications from 2008 through 2009, the faculty of the Atmo- spheric Sciences Department at Texas A\&M University cited journal articles as their primary source format at 91 percent of the total citations, followed by books as the secondary format at 5 percent. The most frequently cited journal titles satisfied the $80 / 20$ Rule, with 80 percent of the most cited journal titles being fulfilled by just 8 percent of the titles. The authors had not expected the article citations to be concentrated in so few journals. These most cited journals (the journals containing 80 percent of the citations) are all available electronically through TAMU Libraries. These most cited journals (the journals containing 80 percent of the citations) form a core journal list for these researchersproviding key collection development knowledge to the TAMU Libraries. Of the nonjournal publications cited, 84.3 percent were owned by the libraries or were freely accessible on the Internet. The age of the publications cited is primarily current, although some older materials are cited as well. Overall, it is clear that the TAMU Libraries' collection for this group of researchers meets their needs quite well.

Academic libraries could benefit from a citation analysis for a particular department, subject area, or broader discipline to determine how well their library is providing access to the most cited journal and nonjournal items and discovering any coverage gaps. While the current study showed that the TAMU Libraries' journal collection served the atmospheric sciences faculty's need well, it did identify other material for possible acquisition. In hard economic times, many libraries are forced to cancel journals. So the results could also form the beginnings of a broader list of infrequently used titles (across multiple departments) as candidates for potential cancellation or for storage. Currently, the authors of this study have a similar project underway in the area of Aerospace Engineering, and several colleagues are undertaking similar studies in nonscience subjects. 


\section{Notes}

1. "Research and Teaching in Atmospheric Science at Texas A\&M University," Department of Atmospheric Sciences, Texas A\&M University, available online at http://atmo.tamu.edu/files/ tamu_atmo_overview.pdf [accessed 20 October 2011].

2. Reba Leiding, "Using Citation Checking of Undergraduate Honors Thesis Bibliographies to Evaluate Library Collections," College \& Research Libraries 66, no. 5 (Sept. 2005): 417-29; Erin T. Smith, "Assessing Collection Usefulness: An Investigation of Library Ownership of the Resources Graduate Students Use," College \& Research Libraries 64, no. 5 (Sept. 2003): 344-55.

3. Leiding, "Using Citation Checking of Undergraduate Honors Thesis Bibliographies," 417-29; Graham Sherriff, "Information Use in History Research: A Citation Analysis of Master's Level Theses," portal: Libraries and the Academy 10, no. 2 (Apr. 2010): 165-83; Smith, "Assessing Collection Usefulness," 344-55.

4. Mark Crotteau, "Support for Biological Research by an Academic Library: A Journal Citation Study," Science \& Technology Libraries 17, no. 1 (1997): 67-86; Katherine W. McCain and J.E. Bobick, "Patterns of Journal Use in a Departmental Library: A Citation Analysis," Journal of the American Society for Information Science 32 (July 1981): 257-67; Laura N. Miller, "Local Citation Analysis of Graduate Biology Theses: Collection Development Implications," Issues in Science $\mathcal{E}$ Technology Librarianship, no. 64 (Winter 2011), available online at www.istl.org/11-winter/index. html [accessed 2 May 2011]; Yelena Pancheshnikov, "A Comparison of Literature Citations in Faculty Publications and Student Theses as Indicators of Collection Use and a Background for Collection Management at a University Library," Journal of Academic Librarianship 33, no. 6 (Dec. 2007): 674-83; Rosalind Walcott, "Serials Cited by Marine Sciences Research Center Faculty, University at Stony Brook, 1986-1991," Science \& Technology Libraries 14 (Spring 1994): 15-33.

5. Nuria Vallmitjana and L. G. Sabate, "Citation Analysis of Ph.D. Dissertation References as a Tool for Collection Management in an Academic Chemistry Library," College \& Research Libraries 69, no. 1 (Jan. 2008): 72-81.

6. Angela M. Gooden, "Citation Analysis of Chemistry Doctoral Dissertations: An Ohio State University Case Study," Issues in Science \& Technology Librarianship, no. 32 (Fall 2001), available online at www.istl.org/01-fall/index.html [accessed 2 May 2011].

7. Thomas W. Conkling, Kevin R. Harwell, Cheryl McCallips, Sylvia A. Nyana, and Bonnie A. Osif, "Research Material Selection in the Pre-Web and Post-Web Environments: An Interdisciplinary Study of Bibliographic Citations in Doctoral Dissertations," Journal of Academic Librarianship 36, no. 1 (Jan. 2010): 20-31; Rosalind Walcott, "Characteristics of Geoscience Doctoral Dissertations Accepted in the United States Academic Institutions 1981-1985," Science \& Technology Libraries 12 (Winter 1991): 5-16.

8. Conkling et al., "Research Material Selection in the Pre-Web and Post-Web," 20-31; Gooden, "Citation Analysis of Chemistry Dissertations"; Leiding, "Using Citation Checking of Undergraduate Honors Thesis Bibliographies," 417-29; Miller, "Local Citation Analysis of Graduate Biology Theses"; Pancheshnikov, "A Comparison of Literature Citations," 674-83; Smith, "Assessing Collection Usefulness," 344-55; Vallmitjana and Sabate, "Citation Analysis of Ph.D. Dissertation References," 72-81; Walcott, "Characteristics of Geoscience Doctoral Dissertations," 5-16.

9. Leiding, "Using Citation Checking of Undergraduate Honors Thesis Bibliographies," $417-29$.

10. Smith, "Assessing Collection Usefulness," 344-55.

11. McCain and Bobick, "Patterns of Journal Use," 257-67; Pancheshnikov, "A Comparison of Literature Citations," 674-83.

12. Paul Kelsey and Tom Diamond, "Establishing a Core List of Journals for Forestry: A Citation Analysis from Faculty at Southern Universities," College \& Research Libraries 64, no. 5 (Sept. 2003): 357-77; McCain and Bobick, "Patterns of Journal Use," 257-67; Miller, "Local Citation Analysis"; Vallmitjana and Sabate, "Citation Analysis of Ph.D. Dissertation References," 72-81.

13. Gooden, "Citation Analysis of Chemistry Doctoral Dissertations"; Miller, "Local Citation Analysis"; Walcott, "Characteristics of Geoscience Doctoral Dissertations," 5-16.

14. Marian A. Burright, Trudi Bellardo Hahn, and Margaret J. Antonisse, "Understanding Information Use in a Multidisciplinary Field: A Local Citation Analysis of Neuroscience Research," College E Research Libraries 66, no. 3 (May 2005): 198-210; Conkling et al., "Research Material Selection," 20-31; Smith, "Assessing Collection Usefulness," 344-55.

15. Burright et al., "Understanding Information Use in a Multidisciplinary Field," 198-210; Miller, "Local Citation Analysis of Graduate Biology Theses"; Pancheshnikov, "A Comparison of Literature Citations," 674-83; Vallmitjana and Sabate, "Citation Analysis of Ph.D. Dissertation References," 72-81.

16. Vallmitjana and Sabate, "Citation Analysis of Ph.D. Dissertation References," 72-81. 
17. Gooden, "Citation Analysis of Chemistry Doctoral Dissertations."

18. Miller, "Local Citation Analysis of Graduate Biology Theses."

19. Burright et al., "Understanding Information Use in a Multidisciplinary Field," 198-210; Conkling et al., "Research Material Selection in the Pre-Web and Post-Web Environments," 20-31; Walcott, "Characteristics of Geoscience Doctoral Dissertations," 5-16.

20. Walcott, "Characteristics of Geoscience Doctoral Dissertations," 5-16.

21. Conkling et al., "Research Material Selection in the Pre-Web and Post-Web Environments," $20-31$.

22. Smith, "Assessing Collection Usefulness," 344-55.

23. Conkling et al., "Research Material Selection in the Pre-Web and Post-Web Environments," $20-31$.

24. Smith, "Assessing Collection Usefulness," 344-55.

25. Leiding, "Using Citation Checking of Undergraduate Honors Thesis Bibliographies," $417-29$. $20-31$.

26. Conkling et al., "Research Material Selection in the Pre-Web and Post-Web Environments,"

27. Smith, "Assessing Collection Usefulness," 344-55.

28. Kelsey and Diamond, "Establishing a Core List of Journals for Forestry," 357-77; McCain and Bobick, "Patterns of Journal Use," 257-67; Miller, "Local Citation Analysis of Graduate Biology Theses"; Vallmitjana and Sabate, "Citation Analysis of Ph.D. Dissertation References," 72-81.

29. Thomas E. Nisonger, "The 80/20 Rule and Core Journals," The Serials Librarian 55, no. 1/2 (2008): 62-84.

30. Leiding, "Using Citation Checking of Undergraduate Honors Thesis Bibliographies," $417-29$.

31. Crotteau, "Support for Biological Research," 67-86.

32. Walcott, "Serials Cited by Marine Sciences Research Center Faculty," 15-33. 29.

33. Conkling et al., "Research Material Selection in the Pre-Web and Post-Web Environments,"

34. Smith, "Assessing Collection Usefulness," 344-55.

35. Miller, "Local Citation Analysis of Graduate Biology Theses."

36. Burright et al., "Understanding Information Use in a Multidisciplinary Field," 198-210; Conkling et al., "Research Material Selection in the Pre-Web and Post-Web Environments," 20-31; McCain and Bobick, "Patterns of Journal Use," 257-67; Smith, "Assessing Collection Usefulness," 344-55.

37. B.C. Griffith, P.N. Servi, A.L. Anker, and M.C. Drott, "The Aging of Scientific Literature: A Citation Analysis," Journal of Documentation 35, no. 3 (1979): 179-96, quoted in Katherine W. McCain and J.E. Bobick, "Patterns of Journal Use in a Departmental Library: A Citation Analysis," Journal of the American Society for Information Science 32 (July 1981): 265.

38. Smith, "Assessing Collection Usefulness," 344-55; Vallmitjana and Sabate, "Citation Analysis of Ph.D. Dissertation References," 72-81. 